ks. Tadeusz Syczewski

\title{
Znaczenie postaw i gestów dla świadomego udziału we Mszy świętej
}

Sobór watykański II w Konstytucji o liturgii przypomina, ze nasze spotkanie z Panem Bogiem urzeczywistnia się pod osłoną znaków. Uwielbienie Stwórcy i uświęcenie człowieka dokonuje się w liturgii poprzez święte znaki widzialne ${ }^{1}$. Liturgia sama w sobie jest znakiem rzeczywistości nadprzyrodzonej $^{2}$. Znaki liturgiczne nie są dziełem przypadku, ale zostały wybrane przez Zbawiciela lub przez Kościół dla oznaczenia niewidzialnych spraw Bożych ${ }^{3}$.

Katechizm Kościota Katolickiego podkreśla, że „znaki i symbole zajmują ważne miejsce w życiu ludzkim. Człowiek, jako istota zarówno cielesna jak duchowa wyraża i rozumie rzeczywistości duchowe za pośrednictwem znaków i symboli materialnych. Jako istota społeczna człowiek potrzebuje znaków i symboli, by kontaktować się z innymi za pośrednictwem języka, gestów i czynności. To samo odnosi się do jego relacji z Bogiem"4.

Każdy znak w liturgii ma w sobie kilka wymiarów: przypominający, gdyż przypomina dzieło zbawcze Jezusa Chrystusa, mocą którego znak ten działa; następnie wymiar zobowiązujący, ponieważ zobowiązuje do życia godnego chrześcijanina oraz wymiar zapowiadający, gdyż wskazuje na liturgię niebieską i do niej prowadzi $i^{5}$.

Dokumenty soborowe przypominają, by obrzędy liturgiczne odznaczały się przede wszystkim prostotą i klarownością, by dzięki temu były zrozumiane przez wszystkich uczestników liturgii ${ }^{6}$. Przyjmowanie zatem odpowiedniej postawy podczas liturgii i wykonywanie określonych gestów nie są z pewno-

${ }^{1}$ Por. KL 7; A. Verheul, Einführung in die Liturgie, Wien 1964, s. 134; C. Vagaggini, Theologie der Liturgie, Einsiedeln 1959, s. 77-91.

${ }^{2}$ Por. S. Hartlieb, Liturgia, [w:] Katolicyzm A-Z, Lódź 1989, s. 288.

${ }^{3}$ Por. KL 70.

${ }^{4}$ KKK 1146.

${ }^{5}$ Por. T. SINKA, Zarys liturgiki, Gościkowo-Paradyż 1988, s. 81.

${ }^{6}$ Por. KL 34. 
ścią czynnościami pustymi czy też tylko wymogiem prawnym. Każdy z nich wyraża odpowiednie nastawienie człowieka i ma swoją głęboką symbolikę ${ }^{7}$.

Konstytucja o liturgii przypomina, iż należy pobudzać wszystkich wiernych do wykonywania aklamacji, odpowiedzi, pieśni czy też czynności lub gestów oraz przyjmować właściwą postawę ciała, by w ten sposób wierni aktywniej włączyli się w liturgię. Jednakowa postawa ciała, którą winni zachowywać wszyscy uczestnicy liturgii, jest znakiem wspólnoty i jedności całego zgromadzenia, ma także duży wpływ na myśli i uczucia uczestników zgromadzenia liturgicznego. Gesty i postawy ciała w liturgii są znakami miłości.

\section{Postawy w liturgii}

Społeczna i wspólnotowa struktura zgromadzenia liturgicznego domaga się odpowiednich postaw i gestów wykonywanych przez każdego uczestnika liturgii. Wyrażają one wspólnotowe działanie i uczestniczenie w tajemnicy Z Zawiciela ${ }^{8}$. W liturgii znamy następujące najważniejsze postawy ciała: stojąca, klęcząca, siedząca, padnięcie na twarz, kroczenie w procesji.

\section{Postawa stojąca}

Postawa stojąca jest wyrazem szacunku, godności dziecka Bożego, gotowości do słuchania ${ }^{9}$. Jest to postawa wolności, gotowości do tworzenia wspólnoty ${ }^{10}$. W pierwszych wiekach chrześcijanie w postawie stojącej zwracali się ku wschodowi i zanosili wszelkie modlitwy do Boga, z rękami wzniesionymi w górę. Oznacza aktywną postawę człowieka, gotowego do działania, do służby ${ }^{11}$. Wyraża także dziękczynienie, oczekiwanie na zmartwychwstanie. Stąd zrodził się chrześcijański zwyczaj zachowania tej postawy szczególnie w niedzielę, ponieważ niedziela jest „Małą Paschą”, dniem zmartwychwstania Chrystusa, jak również w okresie Wielkanocy. Ta postawa jest znakiem łączności ze zmartwychwstałym Panem ${ }^{12}$. Postawa stojąca jest znakiem eschatycznym, to postawa ludzi oczekujących z nadzieją powtórnego przyjścia Pana na ziemię ${ }^{13}$. Pismo Święte mówiąc o prawdzie eschatycznej, używa pojęcia „stanie”. „Serafini” stoją przed Bogiem (por. Iz 6, 2). Anioł Rafał jest jednym z siedmiu aniołów, „którzy stoją w pogo-

${ }^{7}$ Por. T. SinKa, Symbole liturgiczne, Kraków 1991, s. 27.

${ }^{8}$ B. NAdOLSKI, Liturgika, t. I, Liturgika fundamentalna, Poznań 1989, s. 122.

${ }^{9}$ Por. L. JAcouet, Les Psaumes et le coeur de l'homme, Paris, III, s. 793.

${ }^{10}$ Por. A. KuHE, Segni e simboli nel culto e nella vita, Milano 1989, s. 12.

${ }^{11}$ Por. S. CZERwiK, Symbole wspólnototwórcze w celebracji Eucharystii, „Studia Theologica Varsaviensia” 38 (2000) nr 2, s. 79.

${ }^{12}$ Por. A. Kune, Segni e simboli nel culto e nella vita, dz. cyt., s. 13.

${ }^{13}$ Por. J. GrześKowiak, Oto wielka Tajemnica wiary, Poznań 1987, s. 72. 
towiu i wchodzą przed majestat Pański" $(\mathrm{Tb} 12,15)^{14}$. Postawa stojąca jest postawą życia; wszystko, co daje oznaki życia, pnie się w górę. W postawie tej ojcowie Kościoła dopatrywali się świętej wolności dzieci Bożych, otrzymanej na chrzcie świętym. Wyraża ona także gotowość wypełniania woli Bożej ${ }^{15}$. Ten, kto stoi, jest w każdym momencie gotowy do wyruszenia w drogę, do działania, do akcji. Jeśli usłyszy wołanie, to może pójść natychmiast. Izraelici w noc przed wyjściem z niewoli egipskiej i wyruszeniem przez pustynię do Ziemi Obiecanej spożywali wieczerzę na stojąco, w gotowości, w pośpiechu.

Obecne przepisy liturgiczne przypominają, iż wierni stoją w czasie Mszy świętej: od wejścia kapłana aż do kolekty włącznie; podczas śpiewu przed Ewangelią i w czasie czytania lub śpiewania Ewangelii, która jest słowem Chrystusa. Następnie należy stać w czasie wyznania wiary i modlitwy powszechnej oraz od modlitwy nad darami aż do Baranku Boży, z wyjątkiem modlitwy epikletycznej i słów przeistoczenia. Stoimy także w czasie modlitwy po Komunii świętej i zakończenia Mszy świętej ${ }^{16}$.

\section{Postawa klęcząca}

Postawa klęcząca jest gestem adoracji, uwielbienia. W liturgii pierwszych wieków klękano także przed świętymi przedmiotami, takimi jak np. ołtarz, kościół, krzyż, jak również przed osobami, np. papieżem, biskupem. Postawa ta oznaczała także pokutę, błaganie, małość przed Stwórcą ${ }^{17}$. Przyklęknąć, tzn. uczynić się małym, uznać czyjąś wyższośćc ${ }^{18}$. Jest to postawa modlitwy. Klękanie ma również wymiar chrystologiczny. Zbawiciel zawsze poddawał swoją wolę woli Ojca, to było Jego pokarmem. Pan Jezus modlił się na klęcząco w Ogrodzie Oliwnym (por. Łk 22, 41). Piotr upadł na kolana i w takiej postawie modlił się przed wskrzeszeniem Tabity (por. Dz 9, 40). W taki też sposób wstawiała się do Chrystusa Pana matka synów Zebedeusza (por. Mt 20, 20). W postawie klęczącej upadło przed Barankiem czworo zwierząt i dwudziestu czterech starców (por. Ap 5, 8). W pierwszych wiekach wierni klękali w czasie modlitwy w dni postu cotygodniowego i podczas okresu wielkiego postu. Dla chrześcijan przyklęknięcie pozostało gestem adoracji, uwielbienia, pokory, modlitwy, oddania, zależności. Uklęk-

${ }^{14}$ Por. M. Lurker, Stać, [w:] Stownik obrazów i symboli biblijnych, dz. cyt., s. 223.

${ }^{15}$ Por. J. GrześKowiak, Oto wielka Tajemnica wiary, dz. cyt., s. 69.

${ }^{16}$ Por. Instrukcja Episkopatu Polski w związku z wydaniem nowego Mszału ołtarzowego (11 III 1987), [w:] Dokumenty duszpastersko-liturgiczne Episkopatu Polski (1966-1993), Lublin 1994, s. 66.

${ }^{17}$ A. KuHe, Segni e simboli nel culto e nella vita, dz. cyt., s. 14.

${ }^{18}$ Por. J. Grześ́́KOWIaK, Oto wielka Tajemnica wiary, dz. cyt., s. 73. 
nąć znaczy modlić się, uczynić się małym, być do dyspozycji. Klękając oddajemy się pod panowanie Jezusa Chrystusa. Klęczenie symbolizuje także posłuszeństwo wierze, jest opowiedzeniem się za Chrystusem jako Królem, Nauczycielem i Dobrym Pasterzem.

Jest to także postawa pokuty. Orygenes pisze: „Zgięcie kolana jest konieczne, jeżeli zamierzamy oskarżyć się ze wszystkich grzechów przed Panem Bogiem i błagać Go o uwolnienie od nich i przebaczenie”. Postawę klęczącą oznaczającą poczucie małości i grzeszności wobec Stwórcy uznawano jako postawę odpowiednią dla modlitwy osobistej.

Obecnie wierni w czasie liturgii eucharystycznej klęczą w czasie modlitwy epikletycznej, przeistoczenia, na słowa: „Oto Baranek Boży; Panie, nie jestem godzien" oraz w czasie przyjmowania Komunii świętej, jeżeli okoliczności na to pozwalają. Natomiast ludzie w starszym wieku i chorzy mogą siedzieć w czasie całej Mszy świętej i nie należy ich niepokoić. W czasie wyznania wiary wszyscy uczestnicy liturgii pochylają się na słowa: „I za sprawą Ducha Świętego przyjął ciało z Maryi Dziewicy i stał się człowiekiem”19. Klękają zaś w uroczystość Zwiastowania Pańskiego i Narodzenia Pańskiego ${ }^{20}$.

\section{Postawa siedząca}

Postawa siedząca jest znakiem władzy i godności ${ }^{21}$. Jest to postawa wypoczynku, odprężenia, spokoju, ciszy ${ }^{22}$. Jest to także najbardziej praktykowana postawa przy spożywaniu posiłku.

W starożytności postawa ta była znakiem głębokiej żałoby i pokuty, gdy łączyła się z płaczem, lamentacjami (Ps 136, 1; Lm 1-5). W liturgii chrześcijańskiej biskup siedział na swojej katedrze i nauczał. Jest to postawa zasłuchania z uwagą i miłością w słowo Boże: „Maria siadła u nóg Pana i przysłuchiwała się Jego mowie" (Łk 10, 39) ${ }^{23}$. Jest to także postawa słuchającego ucznia, kontemplacji, zamyślenia, refleksji. Pozycja siedząca ułatwia również skupienie, przyjęcie słowa i medytację nad usłyszanym słowem ${ }^{24}$.

Obecnie w czasie liturgii eucharystycznej wierni mogą siedzieć podczas czytań i psalmu responsoryjnego, w czasie homilii, przygotowania darów ofiarnych, w czasie rozdzielania Komunii świętej i milczenia po

${ }^{19} \mathrm{MRz}, \mathrm{s.} 13^{*}$.

${ }^{20}$ Por. Instrukcja Episkopatu Polski w związku z wydaniem nowego Mszału ołtarzowego (11 III 1987), [w:] Dokumenty, dz. cyt., s. 66.

${ }^{21}$ Por. J. GrZeŚKOWIAK, Oto wielka Tajemnica wiary, dz. cyt., s. 76.

${ }^{22}$ Por. M. LuRKer, Siedzieć, [w:] Stownik obrazów i symboli biblijnych, Poznań 1989, s. 214.

${ }^{23}$ Por. S. Czerwik, Symbole wspólnototwórcze w celebracji Eucharystii, dz. cyt., s. 80.

${ }^{24}$ Por. T. SinKA, Zarys liturgiki, dz. cyt., s. 85. 
Komunii świętej, czy też dziękczynienia i uwielbienia wobec Jezusa Chrystusa przyjętego w eucharystycznym chlebie ${ }^{25}$.

\section{Padnięcie na twarz}

Padnięcie na twarz jest wyrazem najniższego uniżenia siebie wobec Pana Boga, wyraz najgłębszej modlitwy ${ }^{26}$. Obecnie gest ten ma miejsce na początku liturgii Wielkiego Piątku (dotyczy celebransa), jak również podczas święceń w czasie litanii do Wszystkich Świętych (przystępujących do święceń) ${ }^{27}$.

\section{Kroczenie w procesji}

Kroczenie w procesji jest aktem czci Pana Boga. Jest przypomnieniem kroczenia ludu Starego Przymierza ku Ziemi Obiecanej. Jest także kroczeniem w kierunku Nowej Paschy, ku Jeruzalem, Kalwarii. Procesja liturgiczna celebruje wędrówkę Kościoła ku wieczności, ku Niebieskiemu Jeruzalem. Jest ona obrazem Kościoła pielgrzymującego do Boga w niebie. Liturgia zna różnego rodzaju procesje w ramach Mszy świętej: procesja na wejście, z darami, z Ewangelią, do Komunii świętej. Inne procesje w ramach liturgii to z palmami, ze światłem w Wigilię Paschalną, w Święto Ofiarowania Pańskiego, w Uroczystość Bożego Ciała, czy też Dni Modlitw o dobre urodzaje i za kraje głodujące. Znane są także procesje pogrzebowe, dziękczynne, błagalne, dla przeniesienia relikwii Świętych Pańskich ${ }^{28}$.

Procesja jest formą przepowiadania. Oto idzie nasz Zbawca, nasz Pan. Krzyż niesiony na początku procesji jest Jego znakiem. Księga Pisma Świętego zawiera Jego słowo. Kapłan jest Jego ręką i ustami. Niesione świece mówią o tym, że Jezus Chrystus jest światłem, które oświeca człowieka. Kadzidło i unoszący się z kadzielnicy dym wzywa do oddawania czci Bogu: Jemu niech będzie cześć i chwała.

\section{Gesty liturgiczne}

Wśród gestów wyróżnia się ekspresywne, które towarzyszą słowom, akcentując ich treść, oraz gesty symboliczne, które oznaczają rzeczywistość niedostępną ${ }^{29}$. Następujące gesty mają miejsce w celebracjach liturgicz-

${ }^{25}$ Por. Instrukcja Episkopatu Polski w związku z wydaniem nowego Mszału ołtarzowego (11 III 1987), [w:] Dokumenty, dz. cyt., s. 66; A. KuHE, Segni e simboli nel culto e nella vita, dz. cyt., s. 17-18.

${ }^{26}$ Por. T. SInKA, Zarys liturgiki, dz. cyt., s. 84-85.

${ }^{27}$ Por. Pontyfikat Rzymski, Obrzędy święceń biskupa, prezbiterów i diakonów, wydanie II wzorcowe, Katowice 1999, s. 77.

${ }^{28}$ A. J. ZnAK, Fundamentalne rzeczywistości liturgii, Oleśnica 1992, s. 239-240.

${ }^{29}$ Por. B. NADOLSKI, Liturgika, t. I, Liturgika fundamentalna, dz. cyt., s. 125. 
nych: gest uderzenia w piersi, gesty rąk, gesty skłonu i podnoszenia oczu, gest znaku pokoju.

Gest uderzenia w piersi

Gest uderzenia w piersi w starożytności był znakiem bólu, żałoby, nieszczęścia, smutku, także śmierci. Stanowił część składową kultu zmarłych. Gest ten miał również i inne znaczenie, a mianowicie wyrażał winę i żal, skruchę, ponieważ serce uchodziło między innymi za źródło i siedlisko wszelkiego grzechu ${ }^{30}$.

Św. Augustyn mówi, że ten gest wykonywano przy wyznaniu win ${ }^{31}$. Obecnie w liturgii zrezygnowano $\mathrm{z}$ uderzenia się w piersi w czasie wymawiania słów: „Panie, nie jestem godzien, abyś przyszedł do mnie”, jak również podczas wymawiania słów „Baranku Boży, który gładzisz grzechy świata”, ponieważ formuły te nie są wyznaniem win.

\section{Gesty rąk}

Gesty rąk są w liturgii często stosowane. Należy do nich wznoszenie rozłożonych rąk, które jest wyrazem oczekiwania pomocy z nieba. W tym geście chrześcijanie widzieli pewne podobieństwo do modlącego się Zbawiciela na krzyżu. W liturgii ten gest jest stosowany dzisiaj przy odmawianiu lub śpiewaniu modlitw celebransa (np. modlitwy na początku Mszy świętej - kolekty, modlitwy nad darami, modlitwy po Komunii świętej, przy odmawianiu prefacji, Ojcze nasz). Wzniesione ręce oznaczają to, iż naszą modlitwę kierujemy do Boga, który jest głównym jej adresatem. Gest ten wyraża także oddanie hołdu, podniesienie duszy do Pana Boga, poddanie się Jego woli, bycia do dyspozycji Stwórcy. Jest on znakiem skupienia dla znalezienia Boga w sobie samym ${ }^{32}$.

Gest rozłożonych rąk nazywany jest gestem oranta. Nawiązuje ta myśl do postaci stojącej z uniesionymi rękami w modlitewnym geście. Spotykamy go na ścianach katakumb, na sarkofagach.

Nałożenie rąk jest symbolem akcji ${ }^{33}$. Ręce zwrócone ku bóstwu oznaczały u pogan modlitwę. Nałożenie rąk, wyciągnięcie nad osobą i dotknięcie głowy, uważano za znak zrównania. Wyciągnięcie rąk oznaczało przeniesienie winy własnej na ofiarę. Posiadało także znaczenie lecznicze, uleczenie, gest przekazania Ducha Świętego (1 Kor 12, 1), przekazanie urzędu (Dz 6, 1; 14, 23; Tm 4, 14). Gest ten spotykamy w liturgii sakra-

\footnotetext{
${ }^{30}$ Por. W. GŁowA, red., Stużba Boża, Lubaczów 1989, s. 141.

${ }^{31}$ Por. B. NADOLSKI, Liturgika, t. I, Liturgika fundamentalna, dz. cyt., s. 125.

${ }^{32}$ Por. S. Czerwik, Symbole wspólnototwórcze w celebracji Eucharystii, dz. cyt., s. 82.

${ }^{33}$ A. J. ZnaK, Fundamentalne rzeczywistości liturgii, dz. cyt., s. 244.
} 
mentów inicjacji chrześcijańskiej (sprawowanie Eucharystii, święcenia diakońskie, kapłańskie, biskupie). Przez ten gest Kościół prosi Boga Ojca o uświęcenie, dokonanie „Wielkich Dzieł”.

Gest skłonu i podnoszenia oczu

Skłon jest znakiem głębokiego szacunku, jak również uwielbienia ${ }^{34}$. W liturgii gest ten oznacza szacunek, oddanie czci, usposobienie pokutne ${ }^{35}$. Skłania się głowę przy wymawianiu razem imion Trzech Osób Boskich, Maryi czy świętego, którego wspominamy danego dnia ${ }^{36}$. Skłon oddajemy w stosunku do celebransa (przewodniczącego liturgii). Skłony stosuje się jako znak szacunku dla krzyża, ołtarza i paschału.

Podnoszenie oczu jest wyrazem wzniesienia duszy i myśli ku Stwórcy ${ }^{37}$. Podnoszenie oczu miało zadanie uprzytomnić sobie obecność Boga (por. Ps 122; Ps 123; Łk 16, 23; J 11, 41) ${ }^{38}$. W liturgii jedyną pozostałością tej praktyki jest Pierwsza Modlitwa Eucharystyczna, czyli Kanon Rzymski, w którym celebrans w czasie konsekracji chleba podnosi oczy ku niebu przy wypowiadaniu następujących słów: „On to w dzień przed męką wziął chleb w swoje święte i czcigodne ręce, podniósł oczy ku niebu [...]"39.

\section{Gest znaku pokoju}

Znak pokoju w liturgii nie jest czymś nowym. Obrzęd ten nawiązuje do pierwszych wieków chrześcijaństwa. Znak pokoju początkowo był wymieniany tylko między celebransem a asystą w czasie Mszy świętej uroczystej. Stary Testament podkreśla, że był to normalny pocałunek. Gest ten pełnił funkcję znaku wyrażającego miłość, przyjaźń i pokój ${ }^{40}$. Posługiwano się tym gestem przy spotkaniach na znak zawartego przymierza czy też osiągniętej zgody. Pocałunek potwierdzał zawarcie związku małżeńskiego, jak również więzy przyjaźni. W Nowym Testamencie zaś pocałunek staje się znakiem świętym: „Pozdrawiają was wszyscy bracia. Pozdrówcie się wzajemnie pocałunkiem świętym” (1 Kor 16, 20).

Sposób przekazywania pocałunku pokoju był odmienny w różnych kulturach. Np. w liturgii koptyjskiej ograniczano się do skłonu w kierunku sąsiada i dotknięcia jego ręki. W innych liturgiach stosowano tylko sam skłon.

\footnotetext{
${ }^{34}$ Por. B. NAdOLSKI, Liturgika, t. I, Liturgika fundamentalna, dz. cyt., s. 125.

${ }^{35}$ T. SINKA, Zarys liturgiki, dz. cyt., s. 84.

${ }^{36}$ Por. B. NADOLSKI, Liturgika, t. I, Liturgika fundamentalna, dz. cyt., s. 125.

${ }^{37}$ Por. T. SinKA, Zarys liturgiki, dz. cyt., s. 85.

${ }^{38}$ Por. A. J. ZnAK, Fundamentalne rzeczywistości liturgii, dz. cyt., s. 242.

${ }^{39} \mathrm{MRz}$, s. 308*.

${ }^{40}$ Por. S. CZERwik, Symbole wspólnototwórcze w celebracji Eucharystii, dz. cyt., s. 98.
} 
Spadek przystępujących do Komunii świętej sprawił, że wymienianie świętego pocałunku było mniej żywe. Ceremoniał biskupi z 1600 roku polecał go stosować tylko w mszach uroczystych. Wszystkie liturgie stosowały pocałunek pokoju pod koniec liturgii słowa, na zakończenie wspólnej modlitwy. Tak pozostało do dnia dzisiejszego w liturgii ambrozjańskiej, w której odprawia się Mszę świętą na terenie Mediolanu we Włoszech.

Już w X wieku pocałunek pokoju we Mszy świętej był powszechnie stosowany, przy czym inna była jego forma wśród duchowieństwa, a inna wśród katolików świeckich. W Polsce ten znak pokoju pojawia się w liturgii w XI wieku. Przy przekazywaniu pocałunku pokoju obowiązywała zasada ładu i porządku. Celebrans przekazywał ten znak diakonowi, następnie klerykom według otrzymanych święceń, ci zanosili kolejno do kierownika chóru, kanoników, kapłanów, ludu. W XII-XIV wieku wszyscy uczestnicy liturgii udzielali sobie pocałunku pokoju w nawie Kościoła. Wierni wymieniali go między sobą. Z czasem pocałunek został wyparty przez użycie relikwiarza, zwanego pacyfikałem (od słowa pax, czyli pokój). Najpierw ten pacyfikał całował celebrans, następnie wierni.

W obecnej liturgii pocałunek pokoju obejmuje: modlitwę kapłana o pokój, życzenie pokoju skierowane przez przewodniczącego liturgii do wiernych i ich odpowiedź oraz przekazanie sobie go nawzajem przez uczestników obrzędu. Ogólne wprowadzenie do Mszału Rzymskiego Pawła VI przypomina, że wierni modlą się o pokój i jedność dla Kościoła i dla całej rodziny ludzkiej oraz wyrażają wzajemną miłość, zanim będą uczestniczyć w jednym chlebie ${ }^{41}$. Modlitwa pokoju wchodząca w ten obrzęd brzmi następująco: „Panie Jezu Chryste, Ty powiedziałeś swoim Apostołom: Pokój wam zostawiam, pokój mój wam daję. Prosimy Cię, nie zważaj na grzechy nasze, lecz na wiarę swojego Kościoła i zgodnie z Twoją wolą napełniaj go pokojem i doprowadź do pełnej jedności. Który żyjesz i królujesz na wieki wieków. Amen"42. Nowy Mszał Rzymski w modlitwie tej wprowadził pewne zmiany na niektóre okresy roku liturgicznego, a mianowicie na okres Narodzenia Pańskiego, wielkiego postu, Wielkanocy, w uroczystość Zesłania Ducha Świętego ${ }^{43}$.

Przekazywany pocałunek pokoju jest darem Pana Boga i nie chodzi tutaj wyłącznie o gest ludzkiej życzliwości, miłości, przyjaźni, dobra, pokoju. Pokój, o którym jest tutaj mowa, jest związany z biblijnym szalom, nie wykluczającym także eschatycznego pokoju. W znaku tym zawiera się świadome solidaryzo-

\footnotetext{
${ }^{41}$ Por. OWMR 56.

${ }^{42} \mathrm{MRz}$, s. $372 *-373^{*}$.

${ }^{43}$ Por. tamże.
} 
wanie się wewnętrzne wszystkich uczestników liturgii z tym, co dokonuje się w tajemnicy Eucharystii. W obrzędzie tym uczestnicy liturgii błagają Pana Boga o pokój i jedność dla całego Kościoła i dla całej rodziny ludzkiej oraz wyrażają wzajemną miłość, zanim będą uczestniczyć w jednym chlebie ${ }^{44}$. Podanie komuś ręki zmusza do refleksji, rewizji swej postawy wobec ludzi, zmiany usposobienia, usunięcia wrogości, niechęci, przebaczenia. Ten gest symbolizuje pojednanie nie tylko z tym konkretnym człowiekiem, któremu podaję rękę, ale ze wszystkimi ludźmi, jeśli mam wobec kogoś pewne opory. Ten znak wzywa do miłości, jest wyrazem dobrej woli człowieka. Znak pokoju nie może być pustą formą bez pokrycia. Za tym znakiem muszą isć konkretne czyny. Winienem przede wszystkim przełamać wszelką obojętność wobec drugiego człowieka, mojego brata. Bez przebaczenia, bez miłości nie mam prawa do pełnego uczestnictwa we Mszy świętej: „Jeśli przyniesiesz swój dar przed ołtarz, i tam wspomnisz, że twój brat ma coś przeciwko tobie, [...] idź pierwej pojednaj się z twoim bratem" (Mt 5, 23) ${ }^{45}$. Prawdziwa cześć dla Eucharystii staje się szkołą czynnej miłości bliźniego. Wiemy, że taki jest prawdziwy i pełny porządek miłości, którego nauczył nas Pan: „Po tym wszyscy poznają, żeście uczniami moimi, jeśli będziecie się wzajemnie miłowali’'(J 13, 35). Eucharystia do tej miłości wychowuje nas w sposób najgłębszy, ukazuje bowiem, jaką wartość w oczach Bożych ma każdy człowiek, nasz brat i siostra, skoro każdemu w taki sam sposób Chrystus daje siebie samego pod postaciami chleba i wina. Jeżeli praktykujemy autentyczny kult eucharystyczny, w oczach naszych musi rosnąć godność każdego człowieka. A poczucie tej godności staje się najgłębszym motywem naszego odniesienia do bliźnich.

Według wskazań Konferencji Episkopatu Polski znak pokoju przekazuje się u nas skłonem głowy w kierunku najbliższych uczestników Mszy świętej z jednej i z drugiej strony, z tym, że należy opuszczać słowa: „Pokój nam wszystkim" ${ }^{46}$. Słowa te w wielu regionach stały się aklamacją głośną, co według wyjaśnienia Kongregacji jest niedopuszczalne. W małych grupach znakiem pokoju może być podanie ręki. Zgromadzenie nie wypowiada żadnej aklamacji ${ }^{47}$.

Należy dołożyć wszelkich starań, aby wspólne postawy i gesty liturgiczne były wykonywane w sposób świadomy i godny przez wszystkich uczest-

${ }^{44}$ Por. A. J. ZnAK, Fundamentalne rzeczywistości liturgii, dz. cyt., s. 245.

${ }^{45}$ Por. Z. ZALEwski, Pobożność eucharystyczna, jej cechy i charakter, RBL 39 (1986), s. 313.

${ }^{46}$ Por. Instrukcja Episkopatu Polski w związku z wydaniem nowego Mszału ołtarzowego (11 III 1987), dz. cyt., s. 65.

${ }^{47}$ Por. OWMR, s. [29]. 
ników liturgii. Rozumienie funkcji postaw i gestów w liturgii pozwala ustrzec się przed rutyną i mechanicznym ich wykonywaniem. Do prawidłowego funkcjonowania postaw i gestów liturgicznych jest wprost konieczna ich przejrzystość. Ks. Stanisław Czerwik pisze, że „Słowa i gesty, z których «utkana» jest celebracja, wymagają mistagogii - wtajemniczenia i poczucia odpowiedzialności za powierzone nam «sacrum»"48.

Drohiczyn

KS. TADEUSZ SYCZEWSKI

${ }^{48}$ S. Czerwik, Symbole wspólnototwórcze w celebracji Eucharystii, dz. cyt., s. 104. 